\title{
The Quality of Annual Reporting by Italian Museums: An International Comparison
}

\section{Luca Bambagiotti-Alberti, Giacomo Manetti \& Barbara Sibilio-Parri}

To cite this article: Luca Bambagiotti-Alberti, Giacomo Manetti \& Barbara Sibilio-Parri (2016): The Quality of Annual Reporting by Italian Museums: An International Comparison, International Journal of Public Administration, DOI: 10.1080/01900692.2015.1070361

To link to this article: http://dx.doi.org/10.1080/01900692.2015.1070361

\section{曲 Published online: 15 Mar 2016.}

\section{Submit your article to this journal $₫$}

Џ Article views: 2

Q View related articles $\square$

View Crossmark data ¿ 


\title{
The Quality of Annual Reporting by Italian Museums: An International Comparison
}

\author{
Luca Bambagiotti-Alberti, Giacomo Manetti, and Barbara Sibilio-Parri \\ Department of Economics and Management, University of Florence, Florence, Italy
}

\begin{abstract}
We study the quality of disclosure and the level of accountability of Italian museums using MPADI2 index (Wei et al. 2008; Botes et al. 2013) on a sample of 13 annual reports which, given the legal status of some entities, encompasses the activity of 93 Italian public and private museums, many of which are within the most visited in Italy and worldwide. The results allow for an international comparison with the annual reports of a panel of USA, UK and European museums which have undergone the same MPADI2 analysis, giving an interesting insight about museum different disclosing practices across countries.
\end{abstract}

\section{KEYWORDS}

Accountability; cultural heritage; disclosure; museums; reporting

\section{Introduction}

Museums are cultural institutions that serve society. Although some observers see museums as a type of "economic exploitation," recent work has started to regard museums as institutions that drive innovation and economic development (Throsby, 2001) as well act as a strategic tool that can regenerate society (Lazzeretti, 2012).

It is generally accepted that heritage assets possess both a cultural and an economic value. The cultural value encompasses overlapping social, historical, symbolic, spiritual, aesthetic, and authenticity factors (Mason, 2002). The economic value is often dependent on the cultural value because sound management relies on the sustainability of economic conditions (Goodwin, 2006; Hutter \& Shusterman, 2006). Indeed, to achieve substantial results, each activity of the museum should be inspired by economic effectiveness and cost effectiveness, both of which have a great impact on the sociocultural dimension (Ames, 1994; Gilhespy, 1999). Economic effectiveness, because using public funds without achieving the results do not bring benefits to the community; cost effectiveness, because the waste of public money results in a harm that will be paid for by future generations (Gilhespy, 2001; Paulus, 2003).

In order to evaluate the extent to which Italian museums are able to fulfill the expectations of their different stakeholders in terms of performance and accountability, this study aims at measuring the level of disclosure within their annual reports. To take into consideration the different needs of the various stakeholder, an approach based on multiple dimensions, internal and external, is necessary; for this reason the balanced scorecard (BSC) model will be employed (Kaplan \& Norton, 1996). Adopting multiple perspectives not only allows us to understand if each stakeholder category is given a proper level of information, but it also allows us to identify better means of compliance and determine if informative objectives are met (Gstraunthaler \& Piber, 2007; Turbide \& Laurin, 2009).

The traditional approach of Kaplan and Norton can be adapted to better fit museums in order to enhance the transparency of their reports and improve accountability. Moreover, it can help management and decision-making, on the one hand, and the discharge of information to stakeholders, on the other. Wei, Davey, and Coy (2008) have use an altered version of the BSC approach to create a Museum Performance and Accountability Disclosure Index (MPADI) that measures the level of information museums in New Zealand and the United Kingdom provide to their stakeholders. Drawing on their preliminary conclusions, Botes, Diver, and Davey (2013) used a modified version of the disclosure index (MPADI2), finding evidence that the four perspectives of BSC are emphasized

CONTACT Giacomo Manetti giacomo.manetti@unifi.it Department of Economics and Management, University of Florence, Via delle Pandette, 9, 50132 Florence, Italy.

Color versions of one or more of the figures in the article can be found online at www.tandfonline.com/lpad.

Although the paper is the result of a team effort, Luca Bambagiotti Alberti can be considered the author of sections 4 and 5 , Giacomo Manetti the author of section 2 and 3, Barbara Sibilio Parri the author of section 1. Section 6 has been written by the three authors.

(c) 2016 Taylor \& Francis 
differently in the United States, the United Kingdom, and other European institutions. This study examines Italian museums in order to assess the quality of annual reporting and compare the results with those of the United States, the United Kingdom, and European.

This study offers:

- a framework for discussing the concept of accountability with regards to museums and the characteristics of annual reports in Italy;

- MPADI2 construction items and the methodology used to assess the quality of reporting, draw the sample of analysis, and collect the annual reporting of the Italian museums involved in the study;

- the ranking of Italian museums according to the MPDAI2 index and how they compare to museums in the United States, the United Kingdom, and Europe;

- findings, conclusions, limitations, and future research.

\section{Theoretical framework}

According to the traditional normative approach to nonprofit organizations (NPOs), the concepts of accountability, transparency, and trust are inseparable. Trust and transparency require more accountability because of the pressures from regulators to demonstrate that NPOs are serving a public purpose (thus meriting tax-exempt status) and addressing questions from citizens or donors who want to know if their money is being well spent (Ebrahim, 2010). Scholars describe accountability in terms of a "process of holding actors responsible for actions" (Fox \& Brown, 1998, p. 12) or as "the means by which individuals and organizations report to a recognized authority (or authorities) and are held responsible for their actions" (Edwards \& Hulme, 1996b, p. 967). According to Ebrahim and Weisband (2007), the following components of accountability are involved in third sector organizations and public agencies:

- transparency, which involves collecting information and making it available and accessible for public scrutiny;

- answerability or justification, which requires providing clear reasoning for actions and decisions, so that they may be subject to scrutiny;

- compliance, through the monitoring and evaluation of procedures and outcomes, combined with transparency in reporting those findings; and,
- enforcement or sanctions for shortfalls in compliance, justification, or transparency.

However, according to many scholars, the essence of accountability is answerability, since being accountable means having an obligation to answer questions regarding decisions, activities, and actions (Brinkerhoff, 2004; Ebrahim, 2003a, 2003b).

However, one of the fundamental distinctions in nonprofit accountability literature involves the competing notions of hierarchical and holistic accountability (O’Dwyer \& Unerman, 2008). Hierarchical accountability is markedly instrumental and opportunistic, shortterm in orientation, and favors providing information to those stakeholders who control access to key resources for both resource use and immediate (campaign) impacts (Ebrahim, 2003a; 2003b; Edwards \& Hulme, 2002a; 2002b). Holistic accountability, meanwhile, refers to broader reporting for measuring the actual or potential impacts of NPOs on a broad range of organizations, individuals, and the environment (Edwards \& Hulme, 2002a; Najam, 1996). This can imply quantitative and qualitative mechanisms of accountability concerned with internal control and the grade of mission achievement.

Supporters of holistic accountability (e.g., Ebrahim, 2005; Kearns, 1996) increasingly stress the need for greater downward information to users, the local community, and other relevant stakeholders, underlining the need to pursue responsiveness in their accountability mechanisms (Weber, 1999) and confirming the necessity of intensive stakeholder engagement in decision-making processes as a critical dimension of organizational accountability. Moreover, recent literature stresses the financial, performance, and political nature of nonprofit accountability (Brinkerhoff, 2004; Jordan \& Van Tuijl, 2006). Financial accountability "concerns tracking and reporting on allocation, disbursement, and utilization of financial resources, using the tools of auditing, budgeting, and accounting," and dealing "with compliance with laws, rules, and regulations regarding financial control and management" (Brinkerhoff, 2001, p. 10). In other words, financial accountability involves accounting and reporting disclosure on allocation and utilization of financial resources, using the traditional tools of management control and auditing.

Performance accountability "refers to demonstrating and accounting for performance in light of agreedupon performance targets," focusing on "services, outputs, and results" (Brinkerhoff, 2001, p. 10). It provides both "a verbal link between the presumably deeply held promises and the conduct of those representing the 
nonprofit" (Lawry, 1995, p. 14) and a basis for evaluating organizational performance (Ebrahim, 2003a). It demonstrates and reports on performance in the light of agreed-upon performance targets and focuses on inputs, outputs, outcomes, and impacts. Political accountability, meanwhile, refers to the procedures and mechanisms which ensure that the NPO maintains the public trust and engages stakeholders in responding to their legitimate expectations.

Accountability can take a number of forms: internal or external, formal or informal, vertical or horizontal, bottom-up or top-down (Molnar, 2008). Accountability systems in museums play a fundamental role in legitimizing their function of caring for and celebrating shared cultural heritage. Essentially, the legitimacy of a museum rests on the public trust and, more specifically, on the community's impression of its work (Anderson, 2004; Bud, Cave, \& Haney, 1991; Carnegie \& Wolnizer, 1996; Kavanagh, 1991). A museum's performance and objectives must be communicated in a transparent and fair way to stakeholders in order to provide them with a useful means of making decisions. Thus, accountability and decision usefulness appear to be the most important objectives of public and nonprofit annual reporting (Nelson, Banks, \& Fisher, 2003). Accountability relationships are complicated by the fact that NPOs and public agencies are expected to be accountable to multiple stakeholders: upwards to citizens (public agencies) or to their funders or members (NPOs); downwards to users; and internally to employees, volunteers, and their missions (Ebrahim, 2010; Edwards \& Hulme, 1996a; Kearns, 1996; Lindenberg \& Bryant, 2001; Najam, 1996). Accountability is a relational concept (Ebrahim, 2010), since it changes according to the relationships among actors and across different types of organizations (e.g., membership, service, advocacy network organizations, and public agencies).

NPOs are expected to be accountable for different topics toward different stakeholder categories. According to Ebrahim (2010), accountability can be determined according to four categories of analysis: finances, governance, performance, and mission. These perspectives are not mutually exclusive, but are instead integrative. If NPOs and public agencies must be accountable to multiple actors, they should carefully evaluate what mechanisms of accountability are actually available to them, choosing the means that are more likely to answer their accountability purposes and claims. Hence, multiple types of accountability mechanisms can be used by NPOs and public agencies in practice: reports and disclosure statements, evaluations and performance assessments, self-regulation, participation, and adaptive learning (Ebrahim, 2003a, 2003b).

In the extant literature, the role of the annual report as an instrument of accountability is indubitable (English \& Guthrie, 2000). As Coy et al. (2001, p. 14) state:

The value of the annual report rests in the provision of a wide range of summarized, relevant information in a single document, which enables all stakeholders to obtain a comprehensive understanding of (an entity's) objectives and performance in financial and non-financial terms. No other single source of such information is available to all stakeholders on a routine basis.

Although legal or voluntary disclosure provides a certain degree of accountability to donors, users, the local community, and members, it also allows NPO boards to partially fulfill their fiduciary responsibilities. The nature of these reports varies considerably among countries, and even among the diverse institutions of the same country. Indeed, it is not uncommon for museums to complain about diverse reporting requirements.

Annual reports are significant tools of accountability in that they make available to the public basic data on museum operations. Their presence on museum websites allows stakeholders to easily access their contents. Nevertheless, while the bulk of this information emphasizes upward reporting of financial data to donors and investors, poor attention is paid to downward accountability to stakeholders (Coy et al., 2001; Normanton, 1971; Patton, 1992; Smith, 1971; Stewart, 1984). For this reason, we believe that the information disclosed through annual reporting must be integrated with other types of information and data included in mission, social, and other types of reports that are often voluntarily disclosed by museums. The key point is that downward accountability mechanisms remain underdeveloped and social reporting can help fill in this expectation gap, extending museums' accountability obligations to a wide range of stakeholders including visitors, donors, communities, employees, and government agencies (Paulus, 2003). Prior research in NPOs and corporations suggests that an organization's national/institutional context, which includes legal, regulatory, and professional structures, influences its propensity to issue social, environmental, or mission (hereafter, simply social) reports (Holloway et al., 1999).

Many scholars, especially in the last 10 years, tend to use (neo) institutional theory to understand how social context can influence the choice of managers who initiate and implement social reporting (LarrinagaGonzàlez, 2007; Larrinaga-Gonzàlez \& Bebbington, 2001; Milne \& Patten, 2002; Ball, 2005, 2007) and the 
role of organizational dynamics in the institutionalization process. According to institutional and neo-institutional theories, the decision to initiate the social reporting process (Gray, Owen \& Adams, 2010; Gray et al., 1993) depends on a number of organizational dynamics and on a variety of regulative, normative, and cognitive drivers that are strictly connected to the local context within which the organization is rooted. Institutional literature often focuses on the concept of "institutional isomorphism," which addresses the need to respond to environmental expectations, guaranteeing the organization's survival and increasing the probabilities of success in a particular context. Isomorphism emerges through three different mechanisms: coercive, normative, and mimetic (DiMaggio \& Powell, 1983). According to Larrinaga-Gonzàlez (2007):

- coercion explains social reporting as a response to regulation or consumer pressure;

- normative mechanisms explain social reporting as a response to voluntary initiatives on the grounds of social responsibility linked with new values deeply rooted in the society in absence of explicit laws or regulations that impose social reporting;

- mimetic approaches interpret social reporting as the consequence of a trend or a voluntary practice widespread among an organization's competitors or among local institutions (e.g., public administrations, corporations, and third sector organizations).

In this study, we consider both annual and social reporting practices, since annual reporting is not the only form of accountability and disclosure adopted by Italian museums. The quality of these reporting practices can be evaluated and "measured" using disclosure indices (Coy \& Dixon, 2004). A few studies focusing on the quality of museum reporting and accountability practices have been conducted: for instance, Jackson (1991) in the United Kingdom, Weil (1994) in the United States, Rentschler and Potter (1996) in Australia, Pignataro (2002) in Italy, Christensen and Mohr (2003) in the United States, Gstraunthaler and Piber (2007) in Austria, Da Silva Menezes, Carnegie, and West (2009) in Portugal and Dainelli, Manetti, and Sibilio (2013) in Australia, Canada, France, Germany, Italy, UK, and US.

Wei et al. (2008) and Botes et al. (2013) tried to evaluate the quality of museums' annual reporting using the already cited MPADI and MPADI2. As mentioned before, the two indices are inspired by the BSC approach proposed by Kaplan and Norton (1996). The BSC tries to evaluate the overall performance of an organization using four perspectives: financial (with a profit focus), customers, internal processes, and learning and growth. In a context in which the level of disclosure depends on national or regional laws, as well as on the propensity of organizations to communicate their performance, the BSC framework can help in improving the relevance and materiality of annual reporting in museums (Gambles, 1999). Zimmerman (2009) affirms that the BSC is suitable for museum performance appraisal, since it provides internal management with useful information for decision-making, contributing to improving the NPO's reputation and informing stakeholders of organizational activities (Sarstedt \& Schloderer, 2010).

The MPADI examines the four categories of the BSC framework, replacing the financial dimension category with the organization mission category. In the MPADI model each dimension of the BSC is articulated into subsections that measure specific aspects. All in all, the model foresees 18 performance measures that Wei et al. (2008) applied and tested against the annual reports of 16 museums in The United Kingdom and New Zealand for the years 2002 and 2003. They found-just like Christensen and Mohr (2003) - that the larger the museums, more likely they are to have greater disclosure scores, thus guaranteeing a better respect for their accountability duties. Furthermore, the authors stress that the application of MPADI highlights a lack of disclosure on information about employee satisfaction, budgeting, and customer satisfaction.

In order to improve the MPADI, Botes et al. (2013) added four performance indicators on strategies and critical success factors (under mission and objectives); reputation (under customer/stakeholder); directors' remuneration (under financial position), and online connectivity (under learning and growth). The 22 performance indicators of MPADI2 are shown in Table 1.

The authors applied the MPADI2 to a sample of 30 annual reports for the year 2008, featuring 15 museums from the United Kingdom and Europe, and fifteen from the United States. The selections were made on the basis of the number of visitors annually and of a Google search using the key words "best museums" in the United Kingdom, the United States, and Europe. We found that museums in the United Kingdom and Europe outperformed their North-American counterparts in almost all aspects of the MPADI2 model. Museums in the United Kingdom obtained the highest disclosure scores due to the regulatory frameworks and oversight bodies that prescribe annual reporting requirements. The authors therefore supposed that regulation (as opposed to size) is highly correlated to the quality of annual reporting for museums. We also 
Table 1. The 22 items of MPADI2.

\begin{tabular}{|c|c|}
\hline BSC & MPADI 2 \\
\hline Mission & $\begin{array}{l}\text { M1-Goals, objectives, vision } \\
\text { M2 - Strategies and critical success factors }\end{array}$ \\
\hline Customer/stakeholder & $\begin{array}{l}\text { C1-Visitors } \\
\text { C2-Customers satisfaction } \\
\text { C3-Sponsor, funders and supporters } \\
\text { C4-Partnership with community } \\
\text { C5-Reputation among stakeholders }\end{array}$ \\
\hline Financial perspective & $\begin{array}{l}\text { F1_Financial performance } \\
\text { F2_Financial position } \\
\text { F3-Cash flows } \\
\text { F4-Budget information } \\
\text { F5-Financial review } \\
\text { F6-Director's remuneration }\end{array}$ \\
\hline Internal process & $\begin{array}{l}\text { 11-Museum management } \\
\text { 12-Collections } \\
\text { 13-Exhibitions and events } \\
\text { 14-Educational activities }\end{array}$ \\
\hline Learning and growth & $\begin{array}{l}\text { L1-Staff development } \\
\text { L2-Employee satisfaction } \\
\text { L3-Research and scholarship } \\
\text { L4-Future developments } \\
\text { L5-Online connectivity }\end{array}$ \\
\hline
\end{tabular}

found that, especially among museums in the United States, the reporting quality depends on management attitudes and governance structures. American museums, in fact, are weak in terms of reporting on employee satisfaction, director's remuneration, and customer satisfaction disclosure. Museums in the United Kingdom and Europe, meanwhile, were weak in terms of addressing employee satisfaction, budgeting, and reputation.

In the light of the above, as stated in the introduction, we aim at applying the MPADI2 for the evaluation of the propensity of the most visited Italian museums to disclosure practices using annual or social reports.

\section{The Italian context}

Italy is rich in cultural heritage and history, as evidenced by the presence of a great number of museums, historic residences, manors, castles, towers, and archeological and natural parks. In addition to these signs of culture, palaces, churches, streets, squares, monuments, and tabernacles confirm that Italy, according to a former Minister of Cultural Heritage, is "an open air museum" (Paolucci, 1996, p. 36).

In 2013, there were 4,588 museums operating in Italy, $64.4 \%$ of which were publicly-run while $35.6 \%$ were privately-run (MiBACT, 2014). Museums can be overseen by the state or a specific region, a province or a municipality. According to Italian law, museums are required to use cash accounting methods instead of the accrual accounting methods that for-profit organizations tend to use. Finally, public museums have no financial autonomy: state museums are directly managed by the Ministry of Cultural Heritage and Tourism
(MiBACT), while regional, provincial, and municipal museums are presided over by local authorities. For this reason, they are not obliged to draw up their own financial statements, but this is instead a responsibility of the public entity that oversees them.

The situation for private museums is different: they can keep an accrual accounting and have legal autonomy which imply to issue specific documents, such as financial statements, management commentary, and internal auditing. The main juridical source for museum reporting is the "Atto di indirizzo sui criteri tecnico scientifici e sugli standard di funzionamento e sviluppo dei musei" (D.M. 10/05/2001). This Act states that even when financial statements are not mandatory "the adoption of accounting reports is advised in order to enable the assessment of economic effectiveness, the transparency of the management and the comparability with other museum institutions, also foreign." (D.M. 10/05/2001). Nevertheless, two recent studies of the MiBAC research department (Maresca Compagna, 2005; Maresca Compagna, Di Marco, \& Bucci, 2008) found that museums have scarcely taken into consideration the adoption of accounting reports in order to improve accountability. To stress the importance of accountability, MiBAC formed a committee in December 2006 that was given the task of defining the minimum levels of quality for cultural exploitation activities and formulating the basic principles and criteria for a proper accountability (Montella \& Dragoni, 2010).

Recently, in order to encourage museums to assess their performance and enhance accountability, a MIBACT special interregional cultural committee has issued a document that focused on the analysis of the performances of the museums and on the various reports they discharge to stakeholder. The document is intended to encourage museum directors to voluntary disclose information pertaining not only to the museum's financial situation (which is seldom forwarded to stakeholders, but rather to institutional entities) but also its non-financial situation, including goals, objectives, and results met.

Italian reporting practices for museums are quite different from those of similar foreign institutions. The annual report cannot be produced as a single document, as all the information which is usually enclosed within it is disclosed in various documents. Italian museums, depending on their legal status, are required to prepare a statement of cash flows or an income statement; many of them are endowed with a statute or an internal regulation that explains the mission statement and organizational setup. In addition, some museums complete financial information 
discharging voluntary reports about their activities, the fulfillment of the mission, and their social achievements. This is the only case where internal reports for performance assessment are coupled with external reports that are meant to satisfy the informational needs of the community and stakeholders.

The museums that most often disclose information on a voluntary basis make all these document available on their websites, where additional information can be found about preservation, tutelage, and exploitation activities of the artifacts, as well as total visitors and other information. In this sense, stakeholders have a plurality of sources for collecting the information they are interested in, which, taken together, results in something akin to an annual report.

Finally, for the purpose of this research, many of the most visited museums in Italy (Il Giornale dell'Arte, 2014) are aggregated in a local Government Special Department (GSD) and given public or private legal status. GSD (in Italian, Soprintendenze Speciali per il patrimonio storico, artistico ed etnoantropologico) presides over the most famous museums of Florence, Rome, Venice, and Naples. Other networks instead gather together civic museums in Venice, Florence, Turin and Siena (in Italian, Fondazione Musei Civici di Venezia, l'Ente Comunale Musei Civici Fiorentini, la Fondazione Torino Musei and la Fondazione Musei Senesi). Although many of these museums disclose information regarding their activities to stakeholders, many of them only release mandatory financial statements to their managing entity. Moreover, many of the most visited Italian museums belong to Government Special Departments that in some cases (Florence and Venice) disclose a comprehensive report of activity encompassing aggregate information for all the museums together rather than as a single entity (Soprintendenza Speciale per il patrimonio storico, artistico ed etnoantropologico e per il Polo museale della città di Firenze, 2014; Soprintendenza Speciale per il patrimonio storico, artistico ed etnoantropologico e per il Polo museale della città di Venezia e dei comuni della Gronda lagunare, 2013).

Our sample of analysis consists of Italian public and private cultural institutions (Appendix 1): 25 belong to the GSD of Florence, 5 to the GSD of Venice, 8 to the GSD of Naples, 4 to a Turin foundation, and 43 to a Siena foundation. For each of these "macro entities" only an aggregate disclosure is available. Eight additional museums are included in our sample, all of which have ad hoc disclosure available through their websites. Twenty-five of the museums in this study are among the 80 most visited museums in Italy and three among the 85 most visited museums worldwide (Il Giornale dell'Arte, 2014). All in all, this study has taken into consideration the equivalent of 13 annual reports, 5 prepared by GSDs and 8 by single entities, which encompasses a total of 93 Italian public and private museums, historic residences, palaces, manors, churches, cloisters, and tabernacles.

\section{Methodology}

The disclosure included in the sample of analysis have undergone content analysis, which is widely adopted in corporate disclosure studies (Guthrie et al., 2004) because it allows repeatability and valid inferences from data according to their context (Krippendorf, 1980). Collected disclosures and available annual reports have been assessed and scored independently by two senior researchers in order to reduce subjective decisions about the selection of the anchor item and its relative score (Ingram \& Robbins, 1992). A preliminary test on two reports was conducted to highlight ambiguous or unclear scoring rules and to standardize the classifying capabilities of the researchers. The results of the individual classification were compared and the differences discussed. This preliminary activity resulted in a final set of detection and classification rules. Finally, to enhance comparability with the findings of Botes et al. (2013), and in order to test the alignment of the research team on the scoring procedure, the highest and lowest scoring annual and activity reports of that study have been taken into consideration and scored by researchers. No relevant differences in the assessment have been discovered between independent valuations or actual valuations and the previous findings.

When necessary, researchers discussed different opinions during the scoring process, reaching consensus or possible compromise about the disclosure items under evaluation. According to the previous study on MPADI and MPADI2, and considering that contributions on museum disclosure are still limited in number, items that constitute the MPADI2 index have not been weighted, so they bear the same importance. This reduces eventual bias deriving from deciding which score should be used for items under investigation, and is consistent with previous studies that see little or difference in using weighted or unweighted scores when assessing items disclosed within annual reports (Firth, 1980). Each item has been scored using a six point scale (Coy, 1995) in which a score of 5 represents ideal disclosure and a score of 0 represents missing information. Intermediate points are assigned for degressive steps of $20 \%$ less than the maximum level 
(i.e., if an item is judged $40 \%$ less than the ideal disclosure, it is assigned a score of 3 ).

\section{Results}

The mean performance accountability score across the population (Table 2) is $38 \%(41.16 / 110)$, which is well under the 59\% (64.70/110) reported by American and European museums that have undergone investigation in the original MPADI2 study (Botes et al., 2013). Among Italian museums only 4 annual reports were over the mean score of $50 \%$ (55/110): two of them were prepared by the GSD (Soprintendenze) of Florence and Venice, while the remaining two were from the Turin museum foundation and the MART museum.

With respect to the results attained by American and European museums in the previous MPADI2 study, Italian museums comply more with the disclosure discharged by the former. The index score of Italian museum range from 11 to 63 points while US museums range from 38 to 58 points and European museums from 74 to 91 points. If we consider the BSC categories singularly, Italian museums have a higher quality of disclosure with respect to American museums in terms of mission perspective and learning and growth perspective, while they have a lower quality of disclosure in the remaining perspectives, especially financial and customer/stakeholder ones (Table 2).

Italian museums obtain the best aggregate means in the internal process perspective, with great emphasis given to disclosure relating to exhibition and events (which is the highest scoring item), collections management, and educational activities for the community.

The customer and stakeholder perspective is the second highest mean perspective, as almost all Italian museums disclose information about visitors that go beyond the simple number of visitors. Various analyses are offered, but only in a very few cases do Italian museums measure customer satisfaction and reputation. This is consistent with what happens in both

Table 2. The performance and accountability disclosure index on Italian museums.

\begin{tabular}{|c|c|c|c|c|c|c|c|c|c|c|c|c|c|c|c|}
\hline & $\begin{array}{c}\text { It } 1 \\
\text { FlrGSD }\end{array}$ & $\begin{array}{l}\text { It } 2 \text { Vnz } \\
\text { GSD }\end{array}$ & $\begin{array}{l}\text { It } 3 \text { Nap } \\
\text { GSD }\end{array}$ & $\begin{array}{l}\text { It } 4 \text { Tor } \\
\text { GSD }\end{array}$ & $\begin{array}{l}\text { It } 5 \text { Sna } \\
\text { GSD }\end{array}$ & $\begin{array}{l}\text { It } 6 \\
\text { Mae- }\end{array}$ & $\begin{array}{l}\text { It } 7 \\
\text { Muse } \\
-\end{array}$ & $\begin{array}{c}\text { It } 8 \\
\text { Maxx } \\
-\end{array}$ & $\begin{array}{c}\text { It } 9 \\
\text { Mart- }\end{array}$ & $\begin{array}{l}\text { It } 10 \\
\text { Tdm- }\end{array}$ & $\begin{array}{l}\text { It } 11 \\
\text { Mcv- }\end{array}$ & $\begin{array}{l}\text { It } 12 \\
\text { FSRR- }\end{array}$ & $\begin{array}{l}\text { It } 13 \\
\text { Fbm- }\end{array}$ & $\begin{array}{c}\text { IT } \\
\text { AVG }\end{array}$ & $\begin{array}{c}\text { EU US } \\
\text { AVG }\end{array}$ \\
\hline $\begin{array}{l}\text { M1 GOALS, } \\
\text { VISION }\end{array}$ & 1 & 1 & 0 & 4 & 4 & 0 & 2 & 3 & 5 & 1 & 1 & 4 & 0 & 2.00 & 3.43 \\
\hline M2 Strat. C.F.s. & 1 & 1 & 0 & 4 & 3 & 0 & 1 & 0 & 1 & 0 & 0 & 3 & 0 & 1.08 & 1.97 \\
\hline MISSION AVG & 1.00 & 1.00 & 0.00 & 4.00 & 3.50 & 0.00 & 1.50 & 1.50 & 3.00 & 0.50 & 0.50 & 3.50 & 0.00 & 1.54 & 2.70 \\
\hline C1 VISITORS & 5 & 5 & 0 & 5 & 5 & 0 & 5 & 4 & 5 & 1 & 3 & 4 & 0 & 3.23 & 3.47 \\
\hline $\begin{array}{ll}\text { C2 Customers } \\
\text { sat. }\end{array}$ & 0 & 0 & 0 & 0 & 0 & 0 & 0 & 0 & 3 & 5 & 0 & 3 & 0 & 0.85 & 1.17 \\
\hline $\begin{array}{l}\text { C3 Sponsor, } \\
\text { funders }\end{array}$ & 3 & 4 & 0 & 3 & 3 & 0 & 0 & 4 & 3 & 3 & 0 & 4 & 1 & 2.15 & 4.13 \\
\hline (4 Partnership & 4 & 4 & 0 & 1 & 5 & 0 & 3 & 2 & 3 & 2 & 0 & 3 & 2 & 2.23 & 3.73 \\
\hline C5 Reputation & 0 & 0 & 0 & 0 & 2 & 0 & 0 & 0 & 0 & 4 & 0 & 0 & 0 & 0.46 & 1.40 \\
\hline $\begin{array}{l}\text { Cust./Stakeh. } \\
\text { Avg }\end{array}$ & 2.40 & 2.60 & 0.00 & 1.80 & 3.00 & 0.00 & 1.60 & 2.00 & 2.80 & 3.00 & 0.60 & 2.80 & 0.60 & 1.78 & 2.78 \\
\hline F1 Fin. perfor. & 0 & 0 & 0 & 2 & 1 & 0 & 0 & 0 & 0 & 2 & 0 & 3 & 1 & 0.69 & 4.37 \\
\hline $\begin{array}{ll}\text { F2 Fin. } \\
\\
\text { position }\end{array}$ & 3 & 3 & 0 & 4 & 3 & 4 & 3 & 0 & 0 & 2 & 0 & 4 & 3 & 2.23 & 4.33 \\
\hline F3 Cash flows & 3 & 3 & 2 & 4 & 3 & 4 & 3 & 3 & 4 & 2 & 2 & 2 & 3 & 2.92 & 3.70 \\
\hline Budget & 3 & 3 & 0 & 0 & 0 & 0 & 0 & 0 & 2 & 0 & 0 & 0 & 0 & 0.62 & 0.83 \\
\hline F5 Fin. review & 0 & 0 & 0 & 5 & 0 & 0 & 0 & 0 & 0 & 0 & 0 & 0 & 3 & 0.62 & 3.90 \\
\hline $\begin{array}{ll}\text { F6 } & \text { Dir. } \\
& \text { remuner. }\end{array}$ & 0 & 0 & 0 & 2 & 0 & 5 & 0 & 0 & 2 & 0 & 0 & 0 & 0 & 0.69 & 1.87 \\
\hline Fin. Persp. Avg & 1.50 & 1.50 & 0.33 & 2.83 & 1.17 & 2.17 & 1.00 & 0.50 & 1.33 & 1.00 & 0.33 & 1.50 & 1.67 & 1.29 & 3.17 \\
\hline $\begin{array}{l}\text { Museum } \\
\text { man. }\end{array}$ & 4 & 4 & 0 & 5 & 5 & 1 & 5 & 1 & 5 & 3 & 1 & 3 & 1 & 2.92 & 3.80 \\
\hline Collections & 5 & 5 & 3 & 2 & 4 & 3 & 1 & 5 & 5 & 3 & 2 & 1 & 1 & 3.08 & 3.80 \\
\hline Exh. events & 5 & 5 & 2 & 4 & 1 & & 3 & 5 & 5 & 5 & 4 & 5 & 4 & 4.00 & 4.07 \\
\hline I4 Educ. activ. & 5 & 5 & 1 & 5 & 5 & 3 & 3 & 5 & 5 & 3 & 3 & 5 & 1 & 3.77 & 3.87 \\
\hline Inter. Proc. Avg & 4,75 & 4.75 & 1.50 & 4.00 & 3.75 & 2.33 & 3.00 & 4.00 & 5.00 & 3.50 & 2.50 & 3.50 & 1.75 & 3.41 & 3.88 \\
\hline L1 Staff devel. & 5 & 5 & 0 & 5 & 0 & 0 & 2 & 0 & 5 & 0 & 2 & 2 & 0 & 2.00 & 1.40 \\
\hline $\begin{array}{l}\text { L2 Empl. } \\
\text { satisf. }\end{array}$ & 0 & 0 & 0 & 0 & 0 & 0 & 0 & 0 & 0 & 0 & 0 & 0 & 0 & 0.00 & 0.23 \\
\hline L3 Research & 4 & 4 & 0 & 2 & 4 & 0 & 3 & 3 & 4 & 4 & 3 & 4 & 0 & 2.69 & 3.43 \\
\hline $\begin{array}{c}\text { L4 Future } \\
\text { devel. }\end{array}$ & 0 & 0 & 0 & 2 & 1 & 2 & 0 & 0 & 0 & 3 & 0 & 0 & 0 & 0.62 & 2.73 \\
\hline L5 Online & 3 & 4 & 3 & 4 & 3 & 3 & 2 & 4 & 3 & 3 & 0 & 3 & 3 & 2.92 & 3.07 \\
\hline $\begin{array}{l}\text { conn. } \\
\text { Lear./Growth } \\
\text { Avg }\end{array}$ & 2,40 & 2.60 & 0.60 & 2.60 & 1.60 & 1.00 & 1.40 & 1.40 & 2.40 & 2.00 & 1.00 & 1.80 & 0.60 & 1.65 & 2.17 \\
\hline Index total score & 54 & 56 & 11 & 63 & 52 & 25 & 36 & 39 & 60 & 46 & 21 & 53 & 23 & 41.46 & 64.70 \\
\hline Italian ranking & 4 & 3 & 13 & 1 & 6 & 10 & 9 & 8 & 2 & 7 & 12 & 5 & 11 & & \\
\hline
\end{tabular}


American and European museums. Funders, donors, supporters, and community partnership are taken into account, even if the information is scattered.

The third highest mean perspective is learning and growth; here the item with the best disclosure is online connectivity, which in some case is very accurate, followed by disclosures regarding research and scholarship. Special attention, then, must be paid to disclosure relating to the staff. While staff development, in fact, is well represented, especially among Italian museums, employee satisfaction is the lowest scoring item, with no museums taking into account this essential resource. The situation is no different abroad, as employee satisfaction is the lowest scoring item among American and European museums.

Mission perspective obtains quite a low mean, even though Italian museums seem to consider this kind of disclosure in a manner similar to American museums. Disclosure about goals, objectives, and vision is of a higher quality with respect to information relating to strategies, especially critical success factors which are not explicitly cited within Italian disclosure.

Lastly, the financial position obtained the lowest mean. With the exception of institutions disclosing a complete financial statement, including balance sheets, income statements, notes, and management commentary, the financial information that is usually discharged to stakeholder is quite poor, even insufficient, given the legal status of the museums disclosing it.

\section{Conclusions}

This study considers the annual (and other forms such as activity and social) reporting discharged by several influential Italian museums to assess their level of accountability and compare it to that of European and American museums, using the findings of Botes et al. (2013) as a starting point. The sample of analysis has included 13 annual reports which, given the legal status of some museums, encompasses the activities of a total of 93 Italian public and private museums, historic residences, palaces, manors, churches, cloisters, and tabernacles. Among the 93 museums taken into consideration, 25 are included within the list of the 80 most visited museums in Italy while three out of these 25 are listed also within the list of the 85 most visited museums worldwide. The quality of disclosure and the level of accountability has been measured through the MPADI (2) index, which takes into consideration 22 disclosure items relating to the four perspectives of the BSC framework. The MPADI index, originally developed by Wei et al. (2008), has been modified by Botes et al. (2013) to include four additional performance indicators. The resulting MPADI (2) has been used

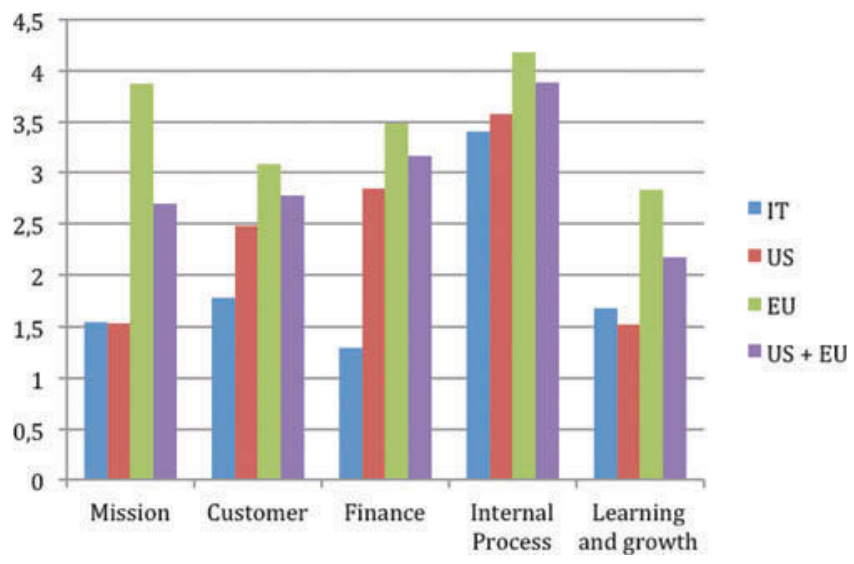

Figure 1. MPADI2 perspective scores comparison: Italian vs. US and European museums.

to analyze the annual reporting of several Italian museums.

The results of the analysis show that Italian museums mean score is lower than other European museums, but similar to American entities (Figure 1). Italian institutions score higher than American institutions in terms of mission and learning and growth perspectives, but score lower in the remaining items, especially financial and stakeholder perspectives. This can be seen as a consequence of the fact that American museums are predominantly funded through private money, while Italian museums in many cases have no financial autonomy, so they are not obliged to draw up their own financial statements. In comparison to European museums, which recorded the highest scores, the low performance of Italian museums is due to a less stringent regulatory framework. As a result, Italian museums, depending on their legal status, discharge different information. Moreover, disclosure is often scattered through multiple sources, making it difficult to properly analyze a comprehensive annual report.

Italian museums obtain the best aggregate means in the internal process perspective, with great emphasis given to disclosure relating to exhibition and events (which is the highest scoring item), collections management, and educational activities for the community. Similarly, the lowest scoring item both in Italy and abroad is employee satisfaction, which often receives no consideration. Conversely, staff development is the only performance indicator out of 22 in which Italian museums show a better level of accountability than American and European museums. With regard to Italy, in addition to employee satisfaction, also customers' satisfaction, reputation, and future development should be significantly improved in order to reach a disclosure level consistent with those of EU and US museums. 
Botes et al. (2013) argued that regulation as opposed to size (Wei et al., 2008) often determines the quality of annual reporting. This seems to be the case with Italian museums, where less stringent regulations led to a low level of accountability. The impact of size on the quality of reporting instead, it's difficult to understand within the Italian context. Bearing in mind that larger museums (say those with more visitors) can better afford the cost of providing information, by receiving a higher level of public and private funding (Wei et al., 2008), the results of the analysis show that museums with the higher scores are not the larger. On the contrary, little museums aggregated within the annual report prepared by GSDs show a good reporting quality despite their limited size (this is the case with Florence and Venice GSD).

Some limitations should be pointed out when interpreting the results of the present research. Museums in Italy disclose information using documents which do not match exactly an annual report and disclosure can be scattered within different sections of museum websites.

Future development of the MPADI 2 index should take into consideration that, considering its BSC derivation, it is naturally designed for internal report and performance management, which is not perfectly suited to improve accountability for stakeholders. Finally, possible developments of the present research include:

- the study of the role played by neo-institutional theory in motivating the issuing of annual reports in diverse national contexts. This type of analysis would need more qualitative research based on specific case studies (including interviews, participatory meetings, and archival analysis) engaging the same institutions involved in the present research and in those conducted by Wei et al. (2008) and Botes et al. (2013);

- an analysis of the fidelity (the degree to which the tool adopted resembles or deviates from a previous "benchmark" version) and extensiveness (the depth to which the tool is implemented) (Ansari et al., 2010) of the information disclosed by those institutions that are forced or warmly recommended by central or local authorities to issue annual reports, following specific guidelines. In fact, the evidence reported by Botes et al. (2013)-museums who obtained the highest disclosure scores (i.e., UK museums) are those who are forced by national regulatory frameworks and oversight bodies to issue annual reports in accordance with specific guidelines-is not unambiguous or clear in the literature (Ansari et al., 2010). In this sense, the hypothesis of Botes et al. (2013) that regulation as opposed to size is highly correlated to the quality of annual reporting for museums is called into question. On the one hand, museums operating in countries where annual reporting is a completely voluntary practice could also obtain reasonable levels of extensiveness in the information disclosed and, consequently, high levels of annual reporting quality. On the other hand, museums operating in countries where annual reporting is a compulsory practice could get diverse results in terms of fidelity and extensiveness of information disclosed, depending on when they join the process.

\section{References}

Ames, P. J. (1994). Measuring museums' merits. In K. Moore (Ed.), Museum management (pp. 22-29). London, UK: Routledge.

Anderson, G. (2004). Reinventing the museum: Historical and contemporary perspectives on the paradigm shift. Lanham, MD: Rowman Altamira.

Ansari, S. M., Fiss, P. C., \& Zajac, E.J. (2010). Made to fit: How practices vary as they diffuse. Academy of Management Review, 35(1), 67-92.

Ball, A. (2005). Environmental accounting and change in UK local government. Accounting, Auditing \& Accountability Journal, 18(3), 346-373.

Ball, A. (2007). Environmental accounting and change: Exploring the institutional toolkit. Proceedings of the 5th Asian-Pacific Interdisciplinary Research in Accounting Conference, Auckland AUS, July 8-10, 8-10.

Botes, V., Diver, R., \& Davey, H. (2013). Preserving the past: An accountability study of the annual reporting practices by leading museums in USA, UK and Europe. Corporate Ownership \& Control, 11(1), 893-906.

Brinkerhoff, D. W. (2001). Taking account of accountability: A conceptual overview and strategic options. Bethesda, MD: Derick W. Brinkerhoff. Abt Associates Inc.

Brinkerhoff, D. W. (2004). Accountability and health systems: Toward conceptual clarity and policy relevance. Health Policy and Planning, 19(6), 371-379. doi:10.1093/heapol/ czh052

Bud, R., Cave, M., \& Haney, S. (1991). Measuring a museum's output. Museums Journal, 91(1), 29-31.

Carnegie, G. D., \& Wolnizer, P. W. (1996). Enabling accountability in museums. Accounting, Auditing \& Accountability Journal, 9(5), 84-99. doi:10.1108/09513579610151962

Christensen, A. L., \& Mohr, R. M. (2003). Not-for-profit annual reports: What do museum managers communicate? Financial Accountability and Management, 19(2), 139-158. doi:10.1111/1468-0408.00167

Coy, D. (1995). A public accountability index for annual reporting by NZ Universities (doctoral thesis), University of Waikato, Hamilton, New Zealand.

Coy, D., \& Dixon, K. (2004). The public accountability index: Crafting a parametric disclosure index for annual reports. 
The British Accounting Review, 36(1), 79-106. doi:10.1016/ j.bar.2003.10.003

Coy, D., Fischer, M., \& Gordon, T. (2001). Public accountability: A new paradigm for college and university annual reports. Critical Perspectives on Accounting, 12(1), 1-31. doi:10.1006/cpac.2000.0416

Da Silva Menezes, C. A., Carnegie, G. D., \& West, B. (2009). The accountability of public museums in Portugal: An exploration of issues. Portuguese Journal of Accounting and Management, 7, 69-96.

Dainelli, F., Manetti, G., \& Sibilio, B. (2013). Web-based accountability practices in non-profit organizations: The case of national museums. Voluntas: International Journal of Voluntary and Nonprofit Organizations, 24(3), 649-665. doi:10.1007/s11266-012-9278-9

DiMaggio, P. J., \& Powell, W. W. (1983). The iron cage revisited: Institutional isomorphism and collective rationality in organizational fields. American Sociological Review, 48(2), 147-160.

Ebrahim, A. (2003a). Making sense of accountability: Conceptual perspectives for northern and southern nonprofits. Nonprofit Management and Leadership, 14(2), 191212. doi:10.1002/nml.v14:2

Ebrahim, A. (2003b). Accountability in practice: Mechanisms for NGO's. World Development, 31(5), 813-829. doi:10.1016/S0305-750X(03)00014-7

Ebrahim, A. (2005). Accountability myopia: Losing sight of organizational learning. Nonprofit and Voluntary Sector Quarterly, 34(1), 56-87. doi:10.1177/0899764004269430

Ebrahim, A. (2010). The many faces of nonprofit accountability. Chap. 4. In D. O. Renz (Ed.), The Jossey-Bass handbook of nonprofit leadership and management (3rd ed., pp. 110-121). San Francisco, CA: Jossey-Bass.

Ebrahim, A., \& Weisband, E. (Eds.). (2007). Global accountabilities: participation, pluralism, and public ethics. Cambridge, UK: Cambridge University Press.

Edwards, M., \& Hulme, D. (Eds.). (1996a). Beyond the magic bullet: NGO performance and accountability in the post-cold war world. West Hartford, Connecticut: Kumarian Press.

Edwards, M., \& Hulme, D. (1996b). Too close for comfort? The impact of official aid on nongovernmental organizations. World Development, 24(6), 961-973. doi:10.1016/ 0305-750X(96)00019-8

Edwards, M., \& Hulme, D. (2002a). Beyond the magic bullet? Lessons and conclusions. In M. Edwards, \& A. Fowler (Eds.), NGO management. London, UK: Earthscan.

Edwards, M., \& Hulme, D. (2002b). NGO performance and accountability: Introduction and overview. In M. Edwards, \& A. Fowler (Eds.), NGO management. London, UK: Earthscan.

English, L. (2003). Emasculating public accountability in the name of competition: Transformation of state audit in Victoria. Critical Perspectives on Accounting, 14(1-2), 51-76.

Firth, M. (1980). Raising finance and firms' corporate reporting policies. Abacus, 16(2), 100-115. doi:10.1111/ abac.1980.16.issue-2

Fox, J. A., \& Brown, L. D. (Eds.). (1998). The Struggle for accountability: The world bank, NGOs, and grassroots movements. Cambridge, MA: The MIT Press.

Gambles, I. (1999). A balanced future lies in the cards. Public Finance, 22, 24-25.
Gilhespy, I. (1999). Measuring the performance of cultural organizations: A model. International Journal of Arts Management, 2(1), 38-52.

Gilhespy, I. (2001). The evaluation of social objectives in cultural organizations: A model. International Journal of Arts Management, 4(1), 48-57.

Goodwin, C. (2006). Art and culture in the history of economic thought. In V. A. Ginsburgh, \& D. Throsby (Eds.), Handbook of the economics of art and culture. Amsterdam, the Netherlands: Elsevier.

Gray, R. H., Bebbington, J., \& Walters, D. (1993). Accounting for the environment. London, UK: Chapman Publishing Ltd.

Gray, R. H., Owen, D., \& Adams, C. (2010). Some theories for social accounting? A review essay and a tentative pedagogic categorisation of theorisations around social accounting. In M. Freedman \& B. Jaggi (Eds.), Sustainability, Environmental Performance and Disclosures Advances in Environmental Accounting and Management (Vol. 4, pp. 1-54). Bingley, UK: Emerald Group.

Gstraunthaler, T., \& Piber, M. (2007). Performance measurement and accounting: Museums in Austria. Museum Management and Curatorship, 22(4), 361-375. doi:10.1080/09647770701628628

Guthrie, J., Petty, R., Yongvanich, K., \& Ricceri, F. (2004). Using content analysis as a research method to inquire into intellectual capital reporting. Journal of Intellectual Capital, 5(2), 282-293.

Holloway, J., Ingberman, D., \& King, R. (1999). An analysis of settlement and merit under federal securities law: What will be the effect of the reform of 1995? Journal of Accounting and Public Policy, 18(1), 1-30.

Hutter, M., \& Shusterman, R. (2006). Value and the valuation of art. In V. A. Ginsburgh, \& D. Throsby (Eds.), Handbook of the economics of art and culture. Amsterdam, the Netherlands: Elsevier.

Il Giornale dell'Arte. (2014). I primi cento musei in Italia nel 2013. U. Allemandi \& C., 32(42): Turin, London, New York.

Ingram, R. W., \& Robbins, W. A. (1992). A partial validation of the GASB user needs survey: A methodological note. Research in Governmental and Nonprofit Accounting, 7, 41-52.

Jackson, P. M. (1991). Performance indicators: Promises and pitfalls. In S. Pearce (Ed.), Museum Economics and the community (pp. 41-46). London, UK: The Athlone Press.

Jordan, L., \& Van Tuijl, P. (2006). NGO accountability. Politics, principles and innovations. London, UK: Earthscan.

Kaplan, R. S., \& Norton, D. P. (1996). The balanced scorecard: Translating strategy into action. Boston, MA: Harvard Business School Press.

Kavanagh, G. (1991). The museums profession: Internal and external relations. Leicester, UK: Leicester University Press.

Kearns, K. (1996). Managing for accountability: Preserving the public trust in public and nonprofit organizations. San Francisco, CA: Jossey-Bass.

Krippendorff, K. (1980). Content analysis: An introduction to its methodology. Beverly Hills, CA: Sage Publications.

Larrinaga-Gonzàlez, C. (2007). Sustainability reporting: Insights from neo-institutional theory. In J. Unerman, J. Bebbington, \& B. O'Dwyer (Eds.), Sustainability 
accounting and accountability (Chapter 8, pp. 150-167). London, UK: Routledge.

Larrinaga-Gonzàlez, C., \& Bebbington, J. (2001). Accounting change or institutional appropriation? A case study of the implementation of environmental accounting. Critical Perspectives on Accounting, 12(3), 269-292.

Lawry, R. P. (1995). Accountability and nonprofit organizations: An ethical perspective. Nonprofit Management and Leadership, 6(2), 171-180. doi:10.1002/(ISSN)1542-7854

Lazzeretti, L. (2012). The resurge of the "societal function of cultural heritage". An introduction. City, Culture and Society, 3(4), 229-233. doi:10.1016/j.ccs.2012.12.003

Lindenberg, M., \& Bryant, C. (2001). Going global: Transforming relief and development NGOs. Bloomfield, CT: Kumarian Press.

Maresca Compagna, A. (Ed.). (2005). Strumenti di valutazione per $i$ musei italiani. Esperienze a confronto, Ufficio Studi del Ministero per i beni e le attività culturali. Rome, Italy: Gangemi Editore.

Maresca Compagna, A., Di Marco, S. C., \& Bucci, E. (2008). Musei Pubblico Territorio. Verifica degli standard nei musei statali, Ufficio Studi del Ministero per i beni e le attività culturali. Rome, Italy: Gangemi Editore.

Mason, R. (2002). Assessing values in conservation planning: Methodological issues and choices. Assessing the values of cultural heritage, Research Report, 5-30. Los Angeles, CA: The Getty Conservation Institute.

Milne, M., \& Patten D. (2002). Securing organizational legitimacy: An experimental decision case examining the impact of environmental disclosures. Accounting, Auditing and Accountability Journal, 15(3), 372-405. doi:10.1108/09513570210435889

Ministero dei beni e delle attività culturali e del Turismo (MiBACT). (2014). Minicifre 2013 della cultura. Rome, Italy: Gangemi Editore.

Molnar, M. (2008). The accountability paradigm: Standards of excellence. Theory and research evidence from Hungary. Public Management Review, 10(1), 127-137. doi:10.1080/14719030701763245

Montella, M., \& Dragoni, P. (Eds.). (2010). Musei e valorizzazione dei beni culturali. Bologna, Italy: Clueb.

Najam, A. (1996). NGO accountability: A conceptual framework. Development Policy Review, 14(4), 339-354. doi:10.1111/j.1467-7679.1996.tb00112.x

Nelson, M., Banks, W., \& Fisher, J. (2003). Improved accountability disclosures by Canadian universities. Canadian Accounting Perspectives, 2(1), 77-107. doi:10.1506/1H5W-R5DC-U15T-KJPH

Normanton, E. L. (1971). Public accountability and audit: A reconnaissance. In B. L. Smith, \& D. C. Hague (Eds.), The dilemma of accountability in modern government: Independence versus control. London, UK: Macmillan.

O'Dwyer, B., \& Unerman, J. (2008). The paradox of greater NGO accountability: A case study of Amnesty Ireland. Accounting, Organizations and Society, 33(7-8), 801-824. doi:10.1016/j.aos.2008.02.002

Paolucci, A. (1996). Italia. Paese del museo diffuso. In C. Morigi Govi \& A. Mottola Molfino (Eds.), La gestione dei musei civici. Pubblico o privato? (pp. 33-46). Torino,Italy: Allemandi \& C.

Patton, J. M. (1992). Accountability and governmental financial reporting. Financial Accountability \& Management, 8 (3), 165-180.

Paulus, O. (2003). Measuring museum performance: A study of museums in France and the United States. International Journal of Arts Management, 6(1), 50-64.

Pignataro, G. (2002). Measuring the efficiency of museums in Sicily. In I. Rizzo, \& R. Towse (Eds.), The economics of heritage: A study in the political economy of culture in Sicily (pp. 65-78). Cheltenham, UK and Northampton, MA, USA: Edward Elgar.

Rentschler, R., \& Potter, B. (1996). Accountability versus artistic development: The case for non-profit museums and performing arts organizations. Accounting, Auditing \& Accountability Journal, 9(5), 100-113. doi:10.1108/09513579610151971

Sarstedt, M., \& Schloderer, M. P. (2010). Developing a measurement approach for reputation of nonprofit organizations. International Journal of Nonprofit and Voluntary Sector Marketing, 15(3), 276-299.

Smith, B. R. (1971). Accountability and independence in the contract state. In B. R. Smith, \& D. C. Hague (Eds.), The dilemma of accountability in modern government: Independence versus control. London, UK: Macmillan.

Soprintendenza Speciale per il patrimonio storico, artistico ed etnoantropologico e per il Polo museale della città di Firenze. (2014). Rapporto di attività 2011-2012. Firenze, Italy: Giunti.

Soprintendenza Speciale per il patrimonio storico, artistico ed etnoantropologico e per il Polo museale della città di Venezia e dei comuni della Gronda lagunare. (2013). Rapporto di attività 2012. Venezia, Italy: Marsilio Ed.

Stewart, J. D. (1984). The role of information in public accountability. In A. Hopwood, \& C. Tomkins (Eds.), Issues in public sector accounting. Oxford, UK: Philip Allan.

Throsby, D. (2001). Economics and culture. Cambridge, UK: Cambridge University Press.

Turbide, J., \& Laurin, C. (2009). Performance measurement in the arts sector: The case of the performing arts. International Journal of Arts Management, 11(2), 56-71.

Weber, E. P. (1999). The question of accountability in historical perspective: From Jackson to contemporary grassroots ecosystem management. Administration \& Society, 31(4), 451-494. doi:10.1177/00953999922019201

Wei, T. L., Davey, H., \& Coy, D. (2008). A disclosure index to measure the quality of annual reporting by museums in New Zealand and the UK. Journal of Applied Accounting Research, 9(1), 29-51.

Weil, S. E. (1994). Performance indicators for museums: Progress report from Wintergreen. The Journal of Arts Management, Law, and Society, 23(4), 341-351. doi:10.1080/10632921.1994.9942945

Zimmerman, J. L. (2009). Accounting for decision-making and control (6th International Edition). New York, NY: McGrawHill. 


\section{Appendix}

Museums included in the sample of analysis

\begin{tabular}{|c|c|c|c|c|c|c|c|}
\hline $\begin{array}{l}\text { ID } \\
\text { number }\end{array}$ & $\begin{array}{c}\text { Italian } \\
\text { ranking }\end{array}$ & Museum & City & $\begin{array}{l}\text { Visitors } \\
(2013)\end{array}$ & $\begin{array}{c}\text { Aggregated } \\
\text { museums }\end{array}$ & $\begin{array}{l}\text { Visitors } \\
(2012)\end{array}$ & $\begin{array}{l}\text { Visitors } \\
(2011)\end{array}$ \\
\hline 1 & 1 & Galleria degli Uffizi e Corridoio Vasariano & Firenze & 1.875 .785 & & & \\
\hline 2 & 3 & Galleria dell'Accademia di Firenze & Firenze & 1.257 .261 & & & \\
\hline 3 & 5 & $\begin{array}{l}\text { Palazzo Pitti (Mus. Argenti, Porcellane, Boboli, Galleria } \\
\text { Costume, Bardini) }\end{array}$ & Firenze & 710.523 & \multicolumn{2}{|c|}{ Soprintendenza Fiorentina } & \\
\hline 4 & 14 & Palazzo Pitti (Palatina, Appartamenti, Galleria Arte Mod.) & Firenze & 386.993 & 25 & 5.052 .717 & 5.130 .071 \\
\hline 5 & 21 & Museo delle Cappelle Medicee & Firenze & 300.894 & & & \\
\hline 6 & 35 & Museo nazionale del Bargello & Firenze & 207.240 & & & \\
\hline 7 & 46 & Museo di San Marco & Firenze & 157.281 & & & \\
\hline 8 & 17 & Gallerie dell'Accademia & Venezia & 325.026 & \multicolumn{2}{|c|}{ Soprintendenza Veneziana } & \\
\hline 9 & 24 & Museo Archeologico nazlonale & Venezia & 265.034 & 5 & 747.967 & 771.884 \\
\hline 10 & 84 & Galleria «Giorgio Franchetti» alla $\mathrm{Ca}^{\prime} \mathrm{d}^{\prime}$ Oro & Venezia & 70.255 & & & \\
\hline 11 & 85 & Museo d'Arte Orientale & Venezia & 70.255 & & & \\
\hline 12 & 61 & Museo di Capodimonte & Napoli & 116.627 & \multicolumn{2}{|c|}{ Soprintendenza Napoletana } & \\
\hline 13 & 72 & Castel Sant'Elmo & Napoli & 97.869 & $8^{*}$ & 377.692 & 405.179 \\
\hline 14 & 77 & Museo di San Martino & Napoli & 93.619 & & & \\
\hline 15 & 41 & Gam-Galleria civica d'Arte Moderna e Contemporanea & Torino & 176.048 & \multicolumn{2}{|l|}{ Fondazione Torino Musei } & \\
\hline 16 & 45 & Palazzo Madama & Torino & 161.503 & 4 & 311.490 & 434.712 \\
\hline 17 & 48 & Museo civico e Torre del Mangia & Siena & 153.026 & \multicolumn{2}{|c|}{ Fondazione Musei Senesi } & \\
\hline & & & & & 43 & 656.955 & 577.816 \\
\hline 18 & 9 & Museo delle Antichità Egizie & Torino & 540.297 & & & \\
\hline 19 & 22 & $\begin{array}{l}\text { Muse (Museo delle scienze, Caproni, Botanico, Geologico, } \\
\text { Palafitte) }\end{array}$ & Trento & 300.520 & & & \\
\hline 20 & 23 & MAXXI Museo nazionale delle Arti del XXI secolo & Roma & 300.000 & & & \\
\hline 21 & 39 & Mart e Casa Depero & $\begin{array}{l}\text { Rovereto } \\
\text { (Tn) }\end{array}$ & 177.649 & & & \\
\hline 22 & 57 & Triennale Design Museum & Milano & 126.138 & & & \\
\hline 23 & 65 & Museo di Castelvecchio & Verona & 111.813 & & & \\
\hline 24 & 74 & Fondazione Sandretto Re Rebaudengo & Torino & 97.123 & & & \\
\hline 25 & 79 & Museo di Santa Giulia & Brescia & 80.432 & & & \\
\hline
\end{tabular}

* In 2014, the number of museums of the GSD of Naples has increased from 6 to 8

Source: elaboration from "Il Giornale dell'Arte" May 2014 